\title{
An Analysis of the Students' Writing Skill in Hortatory Exposition Text at the First Semester of Public Administration Study Program of the Faculty of Social and Political Science
}

\author{
Amanda Pradhani Yanwar ${ }^{1}$ \\ ${ }^{1}$ Universitas Bojonegoro \\ email: amandapradhani2@gmail.com
}

\begin{abstract}
This research aimed to describe the students' difficulties in writing Hortatory Exposition Text and describe the students' scores in writing Hortatory Exposition Text. The research was descriptive qualitative research. It was conducted at the first semester of Public Administration Study Program of the faculty of Social and Political Science Universitas B. The population of this research was 40 students of the first semester of Public Administration Study Program of the Faculty of Social and Political Science Universitas B. Simple random sampling was applied to select the sample. The researcher took 3 participants consisting of one low, one medium, and one high student based on English language proficiency level. In collecting the data, the researcher used test, observation, and interview. In analyzing the data, the researcher used a flow model. The result of the research showed that the low-level student (PE) got the lowest score, and the high-level student (JN) got the highest score. In addition, the aspects of writing the students had the most difficulties in were organization, unity, coherence, sentences, and paragraphs.
\end{abstract}

Keywords: Writing skill, hortatory exposition text, writing difficulties.

\begin{abstract}
Abstrak
Tujuan dari penelitian ini adalah untuk mendeskripsikan kesulitan mahasiswa dalam menulis Teks Hortatory Exposition dan untuk mendeskripsikan skor mahasiswa dalam menulis Teks Hortatory Exposition. Penelitian ini merupakan penelitian deskriptif kualitatif. Penelitian ini dilakukan di semester pertama Program Studi Administrasi Publik Fakultas Ilmu Sosial dan Ilmu Politik Universitas B. Populasi penelitian ini adalah 40 mahasiswa semester pertama dari Program Studi Administrasi Publik Fakultas Ilmu Sosial dan Ilmu Politik Universitas B. Dalam penelitian ini, peneliti menggunakan sampel bebas sederhana. Peneliti mengambil 3 partisipan yang terdiri dari satu mahasiswa level rendah, satu mahasiswa level sedang, dan satu mahasiswa level tinggi. Dalam mengumpulkan data, peneliti menggunakan tes, observasi, dan wawancara. Dalam menganalisis data, peneliti menggunakan model aliran. Hasil dari penelitian ini menunjukkan bahwa mahasiswa level rendah (PE) memperoleh skor yang paling rendah dan mahasiswa level tinggi $(\mathrm{JN})$ memperoleh skor yang paling tinggi. Selain itu, aspek dalam menulis yang paling sulit bagi mahasiswa adalah organisasi, kesatuan, \& koherensi dan kalimat \& paragraf.
\end{abstract}

Kata Kunci: Keterampilan menulis, teks hortatory exposition. 


\section{INTRODUCTION}

In the era of globalization, English is one of the international languages that needs to be mastered. English can be a bridge for people to be able to communicate with other people from different countries. In learning English, there are four major skills that need to be mastered, namely Reading, Writing, Listening, and Speaking. According to Mahu (2012), there are several benefits of learning and mastering English as follows:

a. English widens your understanding.

b. English increases your understanding of your own culture.

c. By mastering English, you will enjoy travelling more.

d. Through English, you can discover entertainment from around the world.

e. Speaking English is a tremendous asset for your professional career.

f. By learning English, you develop life skills.

g. Having an understanding of English as a foreign language helps your native language to develop.

h. By learning and mastering English, you can make lifetime friendships.

i. Speaking English can make you stand out when applying for higher education.

Furthermore, Reddy (2016) stated that there are four reasons why learning English is very important, such as:

a. English may not be the most spoken language in the world, but it is the official language in a large number of countries.

b. English is the dominant business language and it has become almost a necessity for people to speak English if they are to enter a global workforce. c. Many of the world's top films, books and music are published and produced in English.

d. Most of the content produced on the Internet (50\%) is in English.

Writing is one of the essential skills in learning English that needs to be mastered. Writing is a productive skill. In learning English at school, the students can learn various genres of text, such as descriptive, recount, narrative, procedure, explanation, exposition, discussion, news item, anecdote, review, and spoof text.

There are some studies that were conducted to find out writing problems of the Indonesian EFL students. Toba, Noor, and Sanu (2019) found out that the Indonesian students had some problems in the aspects of writing, such as vocabulary, content, grammar, mechanics, and organization. Rahmatunisa (2014) reported that the Indonesian students had three categories for the writing problems, namely psychological problems, linguistics problems, and cognitive problems. Furthermore, Husin and Nurbayani (2017) pointed out that the ideas of students' writings were not developed well, the basic grammar was not correctly used, and the logical thinking ability was still low.

At the level of the university, the students must be able to deliver opinions and to organize views well in the text. It will be more appropriate if the students at the university learn how to organize a text well in hortatory exposition text. At the first semester of university, especially at the study program of Public Administration, in which the students learn more regarding of public policies, the students have to be able to provide arguments to convince readers or listeners orally and in writing. When the students construct and write their arguments 
in a hortatory exposition text, they learn to convince the readers through their writings.

Based on the explanation above, the writer would like to do research entitled “An Analysis of Students' Writing Skill in Hortatory Exposition Text at the First Semester of Public Administration Study Program of the Faculty of Social and Political Science." The researcher wanted to find out about the students' scores in writing hortatory exposition text so that the researcher knew about the students' capabilities in writing text, especially hortatory exposition text. In addition, the researcher was interested in investigating the students' difficulties in writing hortatory exposition text. The researcher wanted to know factors that made the students having problems in writing hortatory exposition text.

\section{Writing as a Productive Skill}

Ur (1988) stated that writing is an important thing to convey the message to the readers. Meyers (2005) explained that writing is a communication with the other people using non-verbal way. It consists of three steps, namely 1) brainstorming and organizing your ideas, 2) putting the ideas into good paragraphs in papers, and 3) revising the paragraphs becoming better. In addition, Pretty and Jensen (1980) contended that writing is ability in accordance with what the writer can assume that the readers knows and expects. Writing is a process of expressing thought, feeling, and experience. It is an important way for communicating with the other people, expressing oneself, and discovering the meaning of the message. Writing is a fundamental aspect in being successful in learning process, particularly in writing process in which the students revise throughout the process, moving back and forth among the stages (Harris, 2000; Urquhart and McIver, 2005).

Based on the definition above, writing is a communication way to the other people so that they can get the message well. Through writing, the writer can express ideas, thought, and feeling. The writer should also consider three important things in writing, such as 1) brainstorming and selecting ideas, 2) organizing the ideas to become good paragraphs, and 3) revising and rewriting them to be better paragraphs.

\section{Indicators of a Good Writing}

According to Harris (1969), aspects of writing consist of grammar, form, mechanic, vocabulary, and style. Grammar is related to grammatical form and syntactic pattern. Form refers to the organization of the content. Mechanic is the use of the graphic convection of the language. Vocabulary is related to words. Style refers to the choice of structure and lexical items. Brown (2001) stated that there are six categories for writing assessment, namely: 1) content, 2) organization, 3) discourse, 4) syntax, 5) vocabulary, and 6) mechanics. In addition, Jacobs et al. (1981) in Haswell (2007) stated that the compositions in scoring writing consist of content, organization, vocabulary, language use, and mechanics.

Based on some theories above, the writer concludes that the indicators of writing are content, organization, grammar, mechanic, and vocabulary.

\section{A. Hortatory Exposition Text}

Acoording to Husein and Pulungan (2017), a hortatory exposition text is a kind of text that has an intention to explain the readers or listeners that something should or should not happen or be done. The aim of hortatory exposition text is to persuade the readers or listeners that something should or should not be the case. This 
means that the writer has to explain some arguments related to the topic to convince the readers or listeners.

Generic structure of hortatory exposition text can be explained below (Husein and Pulungan, 2017).

a. An introductory statement

This part contains the announcement of the concerned issue, the point of view of the author, and a question or emotional statement to get the attention of the audience.

b. A series of arguments

This part contains paragraphs to convince the readers or listeners to believe in the author.

c. Recommendation

This part contains statement of what should or should not happen or be done based on the arguments.

There are some common language features of hortatory exposition text (Husein and Pulungan, 2017):

a. Focusing on generic human and nonhuman participants

b. Using Simple Present Tense

c. Using conjunction

d. Using abstract nouns, e.g. culture, belief, consideration, etc.

e. Using action verbs, e.g. value, talk, watch, etc.

f. Using connectives, e.g. firstly, secondly, thirdly, etc.

g. Using modal auxiliaries, e.g. can, will, should, etc.

B. Previous Research

There are two previous studies related to this research. The first previous related study was entitled "An Analysis of the Tenth Grade Student's Writing Ability in Recount Text of SMA Muhammadiyah 1 Metro Odd Semester Academic Year 2011/2012" conducted by Imam Surya Nugraha \& Marzuki Noor (2012). There were similarities and differences between Nugraha \& Noor's study and this study. The similarities were 1) those two studies were about the students' difficulties in writing and 2) and about the students' scores in writing. Meanwhile, there were two differences between this study and Nugraha \& Noor's study. First, Nugraha \& Noor's study was conducted to the tenth grade students of SMA Muhammadiyah 1 Metro, while this study was conducted to the first semester students of Public Administration Study Program of the Faculty of Social and Political Science Universitas B. Second, Nugraha \& Noor's study focused on writing ability in Recount Text, while this study focused on writing skill in Hortatory Exposition Text.

The second previous related study was a study conducted by Suyadi (2017) entitled "An Analysis of Students' Writing Skills in Recount Text at the Eighth Grade Students of SMP Negeri 2 Kota Jambi". There were similarities and differences between Suyadi's study and this study. The similarities were 1) those two studies investigated the students' difficulties in writing and 2) about the students' scores in writing. Meanwhile, there were two differences between this study and Suyadi's study. First, Suyadi's study was conducted to the eighth-grade students of SMP Negeri 2 Kota Jambi. In contrast, this study was conducted to the first semester students of Public Administration Study Program of the Faculty of Social and Political Science Universitas B. Second, Suyadi's study focused on writing skill in Recount Text, while this study focused on writing skill in Hortatory Exposition Text.

\section{METHOD}

The research design for this research was descriptive qualitative. Usman and Akbar (2017) stated that descriptive qualitative 
research is described with the words according to the respondents' opinions, in accordance with the research questions, then analyzed with the words that motivate the respondents' behaviors (thinking, having feelings, and acting), reduced, triangulated, concluded (given meanings by the researcher), and verified (consulted again to the respondents and colleagues).

This research was conducted to the first semester students of Public Administration Study Program of the Faculty of Social and Political Science Universitas B. The participants of this research were 40 students of the first semester of Public Administration of the Faculty of Social and Political Science Universitas B. In selecting the sample, the researcher used simple random sampling. For the sample, the researcher took 3 participants consisting of one low, one medium, and one high student based on English language proficiency level.

\section{Sources of Data}

The researcher gained the data consisting of the scores of the students' writings and the transcripts of the students' interview.

\section{Techniques of Collecting Data}

The researcher used writings and interview to collect the data. The researcher asked the students to write about matters that were related to social and political science. Then, the researcher interviewed the three students about their opinions of writing class and their difficulties of writing hortatory exposition text.

\section{Techniques of Analyzing Data}

In analyzing the data, the researcher used the flow model called as 'interactive model' that was proposed by Miles and Huberman (1994). Miles and Huberman (1994) stated that there were three stages in using the flow model, namely: data reduction, data display, and conclusion drawing/verification. Those stages are described below.

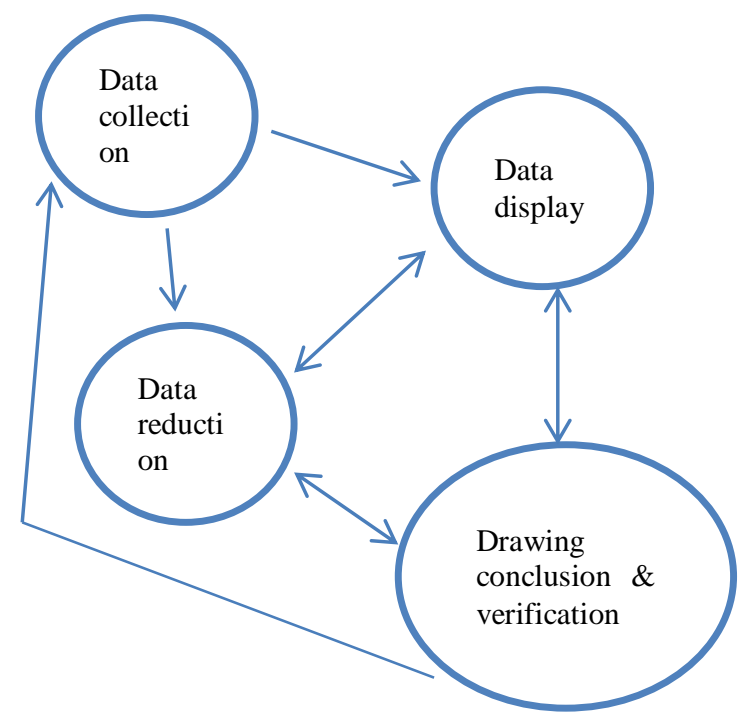

Figure 1: Flow model.

a. Data Reduction

The first stage in using the flow model is data reduction. After collecting the data, the researcher reduced the data by focusing, selecting, and simplifying the data into two categories which were the scores of students' writings in Hortatory Exposition Text and the students' difficulties in writing Hortatory Exposition Text.

b. Data Display

The second stage of the flow model in analyzing the data is data display. After focusing, selecting, and simplifying the data, the researcher displayed the result and discussion by describing and explaining two categories in details, including tables and figures. Those two categories were the scores of students' writings in Hortatory Exposition Text and the students' difficulties in writing Hortatory Exposition Text.

c. Drawing Conclusion and Verification

The third stage of the flow model in analyzing the data is drawing conclusion and verification. After collecting and 
analyzing the data, the researcher concluded what she had found during conducting the research. The researcher drew some conclusions, concluded some implications, and gave some suggestions related to two categories consisting of the scores of students' writings in Hortatory Exposition Text and the students' difficulties in writing Hortatory Exposition Text. In addition, the researcher also suggested other researchers to conduct similar studies investigating different subjects and different focuses on writing skill in different kinds of text.

\section{Trustworthiness}

Trustworthiness is related to reliability and validity. In this research, to verify the trustworthiness, the researcher used triangulation and peer debriefing. In this case, the researcher used methodological triangulation. It means that the researcher used two different techniques in collecting the data: test and interview. The researcher checked the scores of the students' writings and the transcripts of the students' interview. Then, the researcher obtained information whether the results coming from test and interview supported each other or not.

In addition, the researcher chose peer debriefing to verify the trustworthiness of the research because a peer debriefer could have other opinions about the meanings of the findings related to the students' scores in writing and the students' difficulties in writing. It means that the peer debriefer could give critics, suggestions, and recommendations for the researcher's work. In this case, the researcher chose an English master student to become a peer debriefer to check the validity of the data.

\section{FINDING AND DISCUSSION}

This part describes the findings of the research related to the students' scores in writing Hortatory Exposition Text and the students' difficulties in writing Hortatory Exposition Text. The data was analyzed by the researcher using Oklahoma Analytic Scoring Rubric (See Appendix).

The researcher scored the students' writings based on the components of hortatory exposition text (an introductory statement, a series of arguments, \& recommendation). The results of the students' writings can be seen below.

Table 1: The score of the student of the low English language proficiency level.

\begin{tabular}{|c|c|c|c|c|c|}
\hline $\begin{array}{c}\text { Analytic } \\
\text { Traits }\end{array}$ & Weight & & $\begin{array}{c}\text { Trait } \\
\text { Score }\end{array}$ & & $\begin{array}{c}\text { Weighted } \\
\text { Score }\end{array}$ \\
\hline $\begin{array}{c}\text { Ideas and } \\
\text { Development }\end{array}$ & 0.3 & $\mathrm{x}$ & 1 & $=$ & 0.3 \\
\hline $\begin{array}{c}\text { Organization, } \\
\text { Unity, \& } \\
\text { Coherence }\end{array}$ & 0.25 & $\mathrm{x}$ & 1 & $=$ & 0.25 \\
\hline $\begin{array}{c}\text { Sentences \& } \\
\text { Paragraphs }\end{array}$ & 0.15 & $\mathrm{x}$ & 1 & $=$ & 0.15 \\
\hline Word Choice & 0.15 & $\mathrm{x}$ & 1 & $=$ & 0.15 \\
\hline $\begin{array}{c}\text { Grammar, } \\
\text { Usage, \& } \\
\text { Mechanics }\end{array}$ & 0.15 & $\mathrm{x}$ & 1 & $=$ & 0.15 \\
\hline Sum & 1 & $\mathrm{x}$ & 15 & $=$ & 1 \\
\hline Final Score & 15 & & \\
\hline
\end{tabular}

Table 2: The score of the students of the medium English language proficiency level.

\begin{tabular}{|c|c|c|c|c|c|}
\hline $\begin{array}{c}\text { Analytic } \\
\text { Traits }\end{array}$ & Weight & & $\begin{array}{c}\text { Trait } \\
\text { Score }\end{array}$ & & $\begin{array}{c}\text { Weighted } \\
\text { Score }\end{array}$ \\
\hline $\begin{array}{c}\text { Ideas and } \\
\text { Development }\end{array}$ & 0.3 & $\mathrm{x}$ & 3 & $=$ & 0.9 \\
\hline $\begin{array}{c}\text { Organization } \\
\text { Unity, \& } \\
\text { Coherence }\end{array}$ & 0.25 & $\mathrm{x}$ & 2 & $=$ & 0.5 \\
\hline $\begin{array}{c}\text { Sentences \& } \\
\text { Paragraphs }\end{array}$ & 0.15 & $\mathrm{x}$ & 2 & $=$ & 0.3 \\
\hline Word Choice & 0.15 & $\mathrm{x}$ & 3 & $=$ & 0.45 \\
\hline $\begin{array}{c}\text { Grammar, } \\
\text { Usage, \& }\end{array}$ & 0.15 & $\mathrm{x}$ & 2 & $=$ & 0.3 \\
\hline
\end{tabular}


J-SHMIC : Journal of English for Academic

Vol 7, No 2, August 2020

$E-I S S N=2641-1446, P-I S S N=2356-2404$

\begin{tabular}{|c|c|c|c|c|c|} 
Mechanics & & & & & \\
\hline Sum & & & & $=$ & 2.45 \\
\hline Final Score & 2.45 & $\mathrm{x}$ & 15 & $=$ & 36.75 \\
\hline
\end{tabular}

Table 3: The score of the student of the high English language proficiency level.

\begin{tabular}{|c|c|c|c|c|c|}
\hline $\begin{array}{c}\text { Analytic } \\
\text { Traits }\end{array}$ & Weight & & $\begin{array}{c}\text { Trait } \\
\text { Score }\end{array}$ & $\begin{array}{c}\text { Weighted } \\
\text { Score }\end{array}$ \\
\hline $\begin{array}{c}\text { Ideas and } \\
\text { Development }\end{array}$ & 0.3 & $\mathrm{x}$ & 4 & $=$ & 1.2 \\
\hline $\begin{array}{c}\text { Organization, } \\
\text { Unity, \& } \\
\text { Coherence }\end{array}$ & 0.25 & $\mathrm{x}$ & 3 & $=$ & 0.75 \\
\hline $\begin{array}{c}\text { Sentences \& } \\
\text { Paragraphs }\end{array}$ & 0.15 & $\mathrm{x}$ & 3 & $=$ & 0.45 \\
\hline Word Choice & 0.15 & $\mathrm{x}$ & 3 & $=$ & 0.45 \\
\hline $\begin{array}{c}\text { Grammar, } \\
\text { Usage, \& } \\
\text { Mechanics }\end{array}$ & 0.15 & $\mathrm{x}$ & 4 & $=$ & 0.6 \\
\hline Sum & 3.45 & $\mathrm{x}$ & 15 & $=$ & 51.75 \\
\hline Final Score & & & & & 3.45 \\
\hline
\end{tabular}

Based on the data shown in the tables above, the low level student (PE) got the low scores (1 as the lowest trait score) for all aspects, namely ideas and development; organization, unity, and coherence; sentences and paragraphs; word choice; and grammar, usage, and mechanics. The medium level student (BA) got the low scores (2 as the lowest trait score) for organization, unity, and coherence; sentences and paragraphs; and grammar, usage, and mechanics. On the other hand, BA got the high scores (3 as the highest trait score) for ideas and development and word choice. The high student (JN) got the low scores (3 as the lowest trait score) for organization, unity, and coherence; sentences and paragraphs; and word choice. On the other hand, JN got the high scores (4 as the highest trait score) for ideas and development and grammar, usage, and mechanics. In addition, PE got the lowest final score (15), BA got the medium final score (36.75), and JN got the highest final score (51.75).
Based on the interview with the lowlevel student (PE), the researcher got the data as follows:

"I have difficulties in writing hortatory exposition text. I have difficulties in all aspects, whether they are ideas and development; organization, unity, and coherence; sentences and paragraphs; word choice; and grammar, usage, and mechanics. That is because actually I don't really like English. English is difficult. I have to memorize all the vocabularies. I don't know what to do anymore." (Interview taken in March, 2020)

The data above shows that PE did not like English so that she had difficulties in writing hortatory exposition text for all aspects, namely ideas and development; organization, unity, and coherence; sentences and paragraphs; word choice; and grammar, usage, and mechanics. She thought that English was difficult because she had to memorize English vocabularies.

From the interview with the medium level student (BA), the researcher gained the data as follows:

"The difficulties I got during writing hortatory exposition text were about how to organize the sentences and paragraphs so that they can make sense, but I still can develop my ideas well. And also, I had difficulties in about how to create good sentences and paragraphs, and of course, I don't much understand grammar. I hate grammar the most. Sometimes I am also confused to put punctuation in my sentences, paragraphs. Besides I am often 
confused about the spelling of the words. I know many English vocabularies, but sometimes I forget how to spell them." (Interview taken in March, 2020)

The data above shows that BA could develop her ideas well during writing hortatory exposition text. She had difficulties to create good sentences and paragraphs and how to organize the sentences and paragraphs so that they could make sense. In addition, she had problems with grammar. She did not understand grammar a lot. BA also had difficulties to put the correct punctuation in sentences and paragraphs and spell English vocabularies in a good way.

Furthermore, the researcher got the following data based on the interview with the high-level student (JN).

"Actually, I don't have any serious difficulty in writing hortatory exposition text, but sometimes I am a little bit confused about how to organize sentences becoming good paragraphs. Sometimes I am also confused how to choose the appropriate words. But, I like English a lot. That is why I need the lecturer's guidance during the writing. So, I can learn how to organize sentences and paragraphs and choose the most appropriate words." (Interview taken in March, 2020)

Based on the data above, JN liked English very much so that she did not have any serious difficulty in writing hortatory exposition text. Sometimes she was still confused to organize sentences becoming good paragraphs and choose the appropriate words. She still needed the guidance of the lecturer to learn how to write better.

Based on the gained data, the highlevel student (JN) got the highest score, the medium-level student (BA) got the medium score, and the low-level student (PE) got the lowest score. The low-level student said that she did not like English. On the other hand, the high-level student said that she liked English very much.

From the gained data, the students had the most difficulties in the aspect of organization, unity, and coherence and sentences and paragraphs. The students had difficulties to create good sentences and paragraphs and to organize the sentences to become good paragraphs. Pratiwi (2015) stated that writing can be satisfying if we master vocabulary, grammar, punctuation, and idiom. According to Zulfani in Pratiwi (2015), writing is able to help the students to have the stronger writing by adding more grammatical structures, idioms, and vocabulary. In addition, Zulfani in Pratiwi (2015) stated that the students are able to elaborate their ideas in a systematic arrangement by mastering writing skill. Pratiwi (2015) also conveyed that the students need to think how the ideas can be understood by the readers. The authors have to use the correct written language so that the readers are able to understand the ideas of the authors. This means that if the students are able to master the aspects of writing, their writings can deliver the messages to the readers.

\section{CONCLUSION}

Based on the results of the study, the researcher concludes some important issues as follows:

a. One of the reasons the low-level student (PE) got the lowest score is that PE did not like English. 
Meanwhile, one of the reasons the high-level student (JN) got the highest score is that JN liked English very much.

b. The aspects of writing which the students had the most difficulties are organization, unity, and coherence and sentences and paragraphs.

c. This research is important for the readers because it gives information about the difference between the lowlevel student and the high-level student in writing Hortatory Exposition Text. In addition, this research informs the readers about the most difficult aspects for the students in writing.

d. For the future related studies, other researchers can conduct other studies by using other types of text.

\section{REFERENCES}

Brown, D. H. (2001). Teaching by Principles. An Interactive Approach to Language Pedagogy. (2nd ed). New York: Addison Wesley Longman, Inc.

Harris, D. P. (1969). Testing English as a Second Language. McGraw-Hill: New York.

Harris, R. (2000). Rethinking writing. International Journal of Applied Semiotics, 4(2), 131-132.

Haswell, R. H. (2007). Researching teacher evaluation of second language writing via prototype theory, retrieved March 6, 2020 , from http://www.writing.ucsb.edu/wrconf08/ Pdf_Articles/Haswell-Article.pdf.

Husein, R. \& Pulungan, A. H. (2017). Sumber Belajar Penunjang PLPG 2017 Mata Pelajaran/Paket Keahlian Bahasa Inggris $B A B X$ Hortatory Exposition. Kementerian Pendidikan dan Kebudayaan Direktorat Jenderal Guru dan Tenaga Kependidikan.
Husin, M. S. \& Nurbayani, E. (2017). The ability of Indonesian EFL learners in writing academic papers. Dinamika Ilmu, 17(2), 237-250.

Jacobs, H. J., et al. (1981). Testing ESL composition: A practical approach. Rowely, MA: Newbury House.

Mahu, D. P. (2012). Why is learning english so beneficial nowadays? International Journal of Communication Research, 2(4), 374 - 376.

Meyers, T. (2005). (Re)writing Craft: Composition, Creative Writing, and the Future of English Studies, Pittsburgh, PA: The University of Pittsburgh Press.

Miles, M. B. \& Huberman, A. M. (1994a). Qualitative data analysis: An expanded sourcebook (2nd ed.). Thousand Oaks, CA: Sage.

Oklahoma State Department of Education. (2013). Oklahoma school testing program Oklahoma core curriculum tests grade 5 writing: Parent, student, and teacher guide. Retrieved from https://sde.ok.gov/sites/ok.gov.sde/files/ OCCT_GR5_Wr_s13.pdf

Pratiwi, K. D. (2015). Students' difficulties in writing English. Al-Lughah Jurnal Bahasa.

Pretty, W. T. \& Jensen, J. M. (1980). Developing children's language. Boston: Allyn \& Bacon, Inc.

Rahmatunisa, W. (2014). Problems faced by Indonesian EFL learners in writing argumentative essay. English Review: Journal of English Education, 3(1), 1-9.

Reddy, M. S. (2016). Importance of english language in today's world. International Journal of Academic Research, 3(2), 179 $-184$.

Toba, R., Noor, W. N., \& Sanu, L. O. (2019). The current issues of Indonesian EFL students' writing skills: Ability, problem, and reason in writing 
comparison and contrast essay. Dinamika Ilmu, 19(1), 57-73.

Ur, Penny. (1988). English Language Teaching Theory and Practice. Cambridge: Cambridge University Press.

Urquhart, V. \& McIver, M. (2005). Teaching Writing in the Content Areas. MA: Association for Supervision and Curriculum Development.

Usman, H. \& Akbar, P. S. (2017). Metodologi Penelitian Sosial ( $3^{\text {rd }}$ ed.). Jakarta: Bumi Aksara.

Zulfani, R. (2001). A study on learning writing strategies of good language learners (Thesis). Universitas Bengkulu, Bengkulu, Indonesia. 
J-SHMIC : Journal of English for Academic

Vol 7, No 2, August 2020

$E-I S S N=2641-1446, P-I S S N=2356-2404$

\section{APPENDIX}

OKLAHOMA ANALYTIC SCORING RUBRIC - OKLAHOMA WRITING ASSESSMENT 8TH GRADE OCCT

Student's Name Topic/Prompt

\begin{tabular}{|c|c|c|c|c|c|c|c|c|}
\hline \multicolumn{2}{|r|}{\begin{tabular}{l|ll} 
Student's Name & Topic/Prompt \\
Score & Ideas and Development - 30\%
\end{tabular}} & \multicolumn{2}{|c|}{ 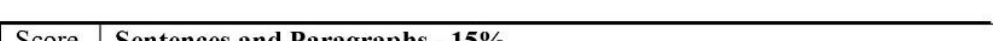 } & & & & & \\
\hline 4 & $\begin{array}{l}\text { The content is well suited for the audience and purpose; main idea or thesis is clear, ideas are fully } \\
\text { developed and elaborated using details, examples, reasons, or evidence; writer expresses an } \\
\text { insightfful perspective towards the topic }\end{array}$ & 4 & & & & & & \\
\hline 3 & $\begin{array}{l}\text { The content is adequate for audience and purpose; main idea is evident but may lack clarity; ideas } \\
\text { are developed using some details, examples, reasons, and/or evidence; writer sustains hisher } \\
\text { perspective toward the topic throughout most of the composition }\end{array}$ & 3 & \multicolumn{6}{|c|}{$\begin{array}{l}\text { Writing adequately demonstrates appropriate sentence structure; writing may contain a small } \\
\text { number of run-on or fragment errors that do not interfere with fluency; writing has adequate } \\
\text { variety of sentence structure; ideas are organized into paragraphs }\end{array}$} \\
\hline 2 & $\begin{array}{l}\text { The content is inconsistent with audience and purpose; main idea is not focused and leaves the } \\
\text { reader with questions; must infer to understand; ideas are minimally developed with few details; } \\
\text { may simply be a list of ideas; writer has difficulty expressing hisher perspective toward topic }\end{array}$ & 2 & \multicolumn{6}{|c|}{$\begin{array}{l}\text { Writing demonstrates lack of control in sentence structure; writing contains errors such as run-ons } \\
\text { and fragments that interfere with fluency; writing has limited variety of sentence structure; writing } \\
\text { may show little or no attempt at paragraphing }\end{array}$} \\
\hline 1 & $\begin{array}{l}\text { The content is irrelevant to the audience and purpose; lacks a central idea; ideas lack development } \\
\text { or may be repetitive; writer has little or no perspective on topic }\end{array}$ & 1 & \multicolumn{6}{|c|}{$\begin{array}{l}\text { Inappropriate sentence structure; many errors in structure (run-ons, fragments); no variety in } \\
\text { structure; no attempt at paragraphing }\end{array}$} \\
\hline \multicolumn{2}{|r|}{ Comment: } & \multicolumn{7}{|c|}{ Comment: } \\
\hline Score & Organization, Unity, and Coherence - $25 \%$ & Score & \multicolumn{6}{|l|}{ Word Choice - 15\% } \\
\hline 4 & $\begin{array}{l}\text { Introduction engages the reader; sustained or consistent focus on the topic; logical and appropriate } \\
\text { sequencing and balanced with smooth, effective transitions; order and structure are strong and } \\
\text { move the reader through the text; conclusion is satisfying }\end{array}$ & 4 & \multicolumn{6}{|c|}{$\begin{array}{l}\text { Appropriate word choice which conveys the correct meaning and appeals to the audience in an } \\
\text { interesting, precise, and natural way; the writing may be characterized by, but not limited to lively } \\
\text { verbs, vivid nouns, imaginative adjectives, figurative language, dialogue; no vague, overused, } \\
\text { repetitive language is used (a lot, great, very, really); words that evoke strong images such as } \\
\text { sensorglanguage- ordinary words used in an unusul way }\end{array}$} \\
\hline 3 & $\begin{array}{l}\text { Evident introduction to the topic; adequate focus; adequate sequencing; stays on topic with little } \\
\text { digression; uses limited but effective transitions; order and structure are present; conclusion is } \\
\text { appropriate }\end{array}$ & 3 & \multicolumn{6}{|c|}{ 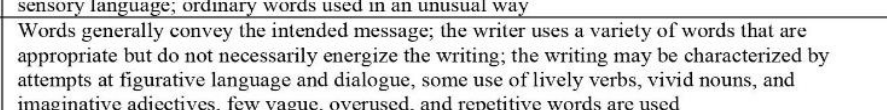 } \\
\hline 2 & $\begin{array}{l}\text { May lack a clear organizational structure; weak evidence of unity; little or limited sequencing } \\
\text { and/or transitions; details may be randomly placed }\end{array}$ & 2 & \multicolumn{6}{|c|}{$\begin{array}{l}\text { Word choice lacks precision and variety or may be inappropriate to the audience and purpose; may } \\
\text { be simplistic and/or vague; relies on overused or vague language (a lot, great, very, really); few } \\
\text { attempts at finurative language and dialoguc; word choice is unimaginative and colorless with } \\
\text { images that are unclear or absent }\end{array}$} \\
\hline 1 & Lacks logical direction; no evidence of organizational structure & 1 & \multicolumn{6}{|c|}{$\begin{array}{l}\text { Word choice indicates an extremely limited or inaccurate vocabulary; no attempts at figurative } \\
\text { language; general, vague words that fail to communicate meaning; text may be too short to } \\
\text { demonotrate variety }\end{array}$} \\
\hline \multicolumn{2}{|l|}{ Comment: } & \multicolumn{7}{|c|}{ Comment: } \\
\hline Score & Grammar, Usage, and Mechanics - 15\% & \multirow{3}{*}{\multicolumn{7}{|c|}{$\begin{array}{l}\text { Students, test your store against the state formula: To calculate, multiply the weights by the trait scores. Sum } \\
\text { un all of the weighted trait scores. Multiply } 15 \text { by the sum of the weighted trait scores. Then round to the } \\
\text { nearest whole number. Composite Scale - } 15 \text { - } 60 \text { - Must have } 36-60 \text { (Satisfactory or Advanced) to pass. } \\
\text { Unsatisfactory } 15 \text { to } 24 \text {, Limited Knowledge } 25 \text { to } 35 \text {, Satisfactory } 36 \text { to } 53 \text {, Advanced } 54 \text { to } 60 \\
\end{array}$}} \\
\hline 4 & $\begin{array}{l}\text { The writer demonstrates appropriate use of correct spelling, punctuation, capitalization, grammar, } \\
\text { usage; errors are minor and do not affect readability }\end{array}$ & & & & & & & \\
\hline 3 & The writer demonstrates adequate use of correct spelling, punctuation, capitalization, grammar, & & & & & & & \\
\hline 2 & $\begin{array}{l}\text { usage; errors may be more noticeable but do not significantly affect readability } \\
\text { The writer demonstrates minimal use of correct spellino punctuation, capitalization, grammar. }\end{array}$ & \multirow{3}{*}{\multicolumn{2}{|c|}{$\begin{array}{c}\text { Analytic Traits } \\
\text { Ideas and Development } \\
\text { Organization, Unity, and Coherence }\end{array}$}} & & & & & \\
\hline & usage; errors may be distracting and interfere with readability & & & .30 & $\mathrm{x}$ & & - & \\
\hline 1 & & & & .25 & $\mathrm{x}$ & & $=$ & \\
\hline & usage; errors are numerous and severely impede readability & \multicolumn{2}{|r|}{$\begin{array}{c}\text { Sentences and Paragraphs } \\
\text { Word Choice }\end{array}$} & .15 & $\mathrm{x}$ & & $=$ & \\
\hline \multirow{3}{*}{ Comment: } & & \multicolumn{2}{|r|}{$\begin{array}{c}\text { Word Choice } \\
\text { Grammar, Usage, and Mechanics }\end{array}$} & $\frac{.15}{15}$ & \begin{tabular}{|l|l|}
$x$ \\
\end{tabular} & & $=$ & \\
\hline & & & & & & & & Sum \\
\hline & & \multicolumn{3}{|c|}{ (Composite [Final] SS } & & & & \\
\hline
\end{tabular}

